\title{
PENGARUH KOMPENSASI DAN MOTIVASI TERHADAP KINERJA KARYAWAN
}

\author{
Anton Hindardjo, Ririn Adi Utami \\ anton.hindardjo@sebi.ac.id \\ Sekolah Tinggi Ekonomi Islam SEBI
}

\begin{abstract}
This research aims to determine the effect of compensation and motivation on employee performance at BMT in the city of Tangerang. Research based on the importance of compensation received by someone in a company related to the increased performance in the company. And motivation in work to obtain maximum result for his work in a company.

The sample in this research was taken using a data collection method called purposive sampling. The number of samples used is as many as 35 respondents. The data obtained were analyzed using PLS (Partial Least Square) analysis techniques through SmartPLS software.

The result of the research indicate that compensation has a positive and insignificant effect on the construct of direct employee performance. And motivation has a significant positive effect on the construct of employee performance directly.

Keywords: Compensation, Motivation, Performance, Partial Least Square (PLS).
\end{abstract}

\section{PENDAHULUAN}

Dalam perkembangan zaman yang semakin maju, keberadaan sumber daya manusia yang handal memiliki peranan yang sangat penting dibandingkan dengan sumber daya yang lainnya. Perusahaan dituntut untuk dapat menciptakan kinerja karyawan yang berkualitas guna menunjang pencapaian tujuan suatu perusahaan. Agar perusahaan mampu menciptakan kinerja karyawan yang berkualitas tinggi, perusahaan perlu memperhatikan salah satu factor yang mempengaruhi kinerja karyawan yaitu kompensasi baik finansial maupun non finansial. ${ }^{1}$

Sadar akan pentingnya sumber daya manusia bagi kelangsungan hidup dan kemajuan suatu perusahaan, maka suatu perusahaan harus memberikan perhatian khusus terhadap sumber daya manusia dan sudah

\footnotetext{
${ }^{1}$ Chrisnanda, Dody. Pengaruh Motivasi Kerja Terhadap Kinerja Karyawan di PT. MAS SUMBIRI. Skripsi. Universitas Sanata Dharma, Yogyakarta. 2017.
} 
sewajarnya pemilik perusahaan memandang sumber daya manusia lebih dari sekedar asset perusahaan dan menjadikan mitra dalam berusaha. Perusahaan harus dapat bersikap adil atas apa yang telah diberikan oleh sumber daya manusia kepada perusahaan, karena setiap karyawan berhak mendapatkan penghargaan dan perlakuan yang adil dari pimpinannya sebagai timbal balik atas jasa yang diberikannya, sehingga dapat mendorong para karyawan untuk lebih termotivasi dalam menjalankan kewajibannya sebagai seorang pekerja. Hubungan kerja yang saling menguntungkan antara perusahaan dan karyawan sangat diperlukan dalam rangka mendorong semangat kerja karyawan. Karyawan memberikan prestasi kerja yang baik untuk kemajuan perusahaan, sedangkan perusahaan memberikan kompensasi yang sesuai atas prestasi kerja yang telah diberikan karyawan terhadap perusahaan. ${ }^{2}$

Menurut Drs. Malayu S.P. Hasibuan, kompensasi adalah semua pendapatan yang berbentuk uang, barang langsung atau tidak langsung yang diterima karyawan sebagai imbalan atas jasa yang diberikan kepada perusahaan. Kompensasi berbentuk uang, artinya kompensasi dibayar dengan sejumlah uang kartal kepada karyawan bersangkutan. Kompensasi berbentuk barang, artinya kompensasi dibayar dengan barang. Misalnya kompensasi dibayar $10 \%$ dari produksi yang dihasilkan. Di Jawa Barat, penuai padi upahnya $10 \%$ dari hasil padi yang di tuainya.

Andrew E. Sikula mengemukakan bahwa:

"The process of wage or salary administration (or, "compensation" as it is sometimes called) involves the weighing or balancing of accounts. A compensation is anything that constitutes or is regarded as an equivalent or recompense. In the employment world, financial rewards are the compensation resources provided to employees for the return of their services. The terms "remuneration", "wage", and "salary" also are used to describe this financial arrangement between employers and employees. A remuneration is a reward, payment, or reimbursements on occasion also may be nonfinancial in nature. Remunerations are usually in the form of comprehensive pay concepts than are the ideas of salary and wage that normally include a financial but not a nonfinancial dimension.

Berdasarkan pendapat Andrew itu dapat dikemukakan bahwa proses administrasi upah atau gaji (kadang-kadang disebut kompensasi) melibatkan

\footnotetext{
${ }^{2}$ Fahmi, Irham. Pengantar Manajemen Sumber Daya Manusia. (Jakarta: Lembaga Mitra Wacana Media, 2016) 95.
} 
pertimbangan atau keseimbangan perhitungan. Kompensasi merupakan sesuatu yang dipertimbangkan sebagai suatu yang sebanding. Dalam kepegawaian, hadiah yang bersifat uang merupakan kompensasi yang diberikan kepada pegawai sebagai penghargaan dari pelayanan mereka. Bentuk-bentuk pemberian upah, bentuk upah, dan gaji digunakan untuk mengatur pemberian keuangan antara majikan dan pegawainya.

Dalam konteks perusahaan, Handoko mengemukakan bahwa suatu cara untuk meningkatkan prestasi kerja, motivasi dan kepuasan kerja karyawan adalah dengan memberikan kompensasi. Hasibuan menyatakan kompensasi adalah semua pendapatan yang berbentuk uang, barang langsung atau tidak langsung yang diterima karyawan sebagai imbalan atas jasa yang diberikan kepada perusahaan. Lebih lanjut Sikula yang di terjemahkan Mangkunegara, mengatakan kompensasi adalah pemberian upah yang merupakan imbalan, pembayaran untuk pelayanan yang telah diberikan oleh karyawan. $^{3}$

Menurut Rivai pada umumnya pemberian kompensasi yang diberikan oleh perusahaan dapat dibedakan dengan dua macam yaitu finansial maupun nonfinansial. Kompensasi finansial merupakan pemberian gaji/upah dan insentif (komisi dan bonus) yaitu setelah karyawan melakukan tugas dan tanggung jawabnya perusahaan wajib memberikan kompensasi finansial sebagai kerja keras karyawan tersebut kepada perusahaan. Berikutnya kompensasi non finansial terdiri atas pekerjaan dan lingkungan kerja, seperti tugas-tugas yang menarik, tantangan baru yang menarik pengakuan, rasa pencapaian, kerabat kerja yang menyenangkan, lingkungan kerja yang nyaman dan sebagainya. Adanya pemberian kompensasi yang sesuai dengan kinerja karyawan diharapkan bahwa karyawan memiliki komitmen sehingga karyawan tersebut akan meningkatkan kinerjanya demi keberhasilan dan kemajuan perusahaan dalam mencapai tujuannya. ${ }^{4}$

Kinerja merupakan suatu hasil kerja yang dihasilkan karyawan. Adapun kinerja menurut Mangkunegara, adalah hasil kerja secara kualitas dan kuantitas yang dicapai oleh seorang karyawan dalam melaksanakan tugasnya sesuai dengan tanggung jawab yang diberikan kepadanya. Kompensasi dan kinerja karyawan merupakan dua factor yang yang berkaitan

\footnotetext{
${ }^{3}$ Fitriani. Pengaruh Motivasi Terhadap Kinerja Pegawai Administrasi Pada Bagian Umum Kantor Walikota Jakarta Utara. Skripsi. Institut Bisnis \& Multimedia, Jakarta: 2011.

${ }^{4}$ Hasibuan, Malayu S.P. Manajemen Sumber Daya Manusia. (Jakarta: PT Bumi Aksara. 2017) 112.
} 
karena pemberian kompensasi akan membawa dampak bagi karyawan yang bersangkutan maupun perusahaan dimana ia bekerja. Kompensasi tersebut harus mempunyai yang menjadi pertimbangan dalam menentukan pembagian kompensasi kepada karyawan tersebut.

Pemberian kompensasi dapat meningkatkan prestasi kerja dan motivasi karyawan. Oleh karena itu, perhatian organisasi atau perusahaan terhadap pengaturan secara rasional dan adil sangat diperlukan. Bila karyawan memandang pemberian kompensasi tidak memadai, prestasi kerja, kinerja, motivasi maupun kepuasan kerja mereka cenderung akan menurun. Salah satu langkah untuk mempertahankan atau meningkatkan kinerja karyawan dapat dilakukan dengan mengevaluasi kinerja karyawan dan melakukan serangkaian perbaikan agar selalu meningkatkan kualitas karyawan tersebut sehingga perusahaan tumbuh dan unggul dalam persaingan, atau minimal tetap dapat bertahan. ${ }^{5}$

Motivasi memiliki hubungan yang erat dengan sikap dan perilaku yang dimiliki oleh seseorang. Sikap yang ada pada setiap individu berinteraksi dengan nilai-nilai, emosi, peran, struktur sosial dan peristiwaperistiwa baru, yang bersama-sama emosi dapat dipengaruhi dan di ubah oleh perilaku. Perubahan sikap ini dimungkinkan karena pikiran manusia adalah suatu kekuatan kompleks yang dapat mengadaptasi, mempelajari, dan memproses setiap informasi dan perubahan baru yang diterimanya. Motivasi itu sendiri dapat diartikan sebagai keadaan dalam diri pribadi seseorang sehingga orang tersebut terdorong untuk melakukan suatu kegiatan atau aktivitas. Oleh karenanya, motivasi mempunyai sifat yang tidak akan lepas dari sifat manusia itu sendiri, dimana manusia secara individual mempunyai kualitas eksistensi diri yang berbeda-beda antara satu dengan yang lainnya.

Penelitian ini dilakukan pada BMT Se-Kota Tangerang. Penelitian ini dilakukan untuk mengetahui sejauh mana pengaruh pemberian kompensasi yang diberikan perusahaan kepada karyawan yang terdiri dari kompensasi finansial dan non finansial terhadap kinerja karyawan juga menganalisis seberapa berpengaruh motivasi kerja terhadap karyawan BMT Se-kota Tangerang. Mengingat pemberian kompensasi serta motivasi kerja sama pentingnya bagi karyawan maka diharapkan pemberian bentuk kompensasi

\footnotetext{
5 Kasiram, Moh. Metode Penelitian Kualitatif-Kuantitatif. (Malang: UIN-Malang Press. 2008) 56.
} 
tersebut juga motivasi yang ada sama-sama dapat memberikan dampak yang positif bagi karyawan untuk meningkatkan kinerja.

\section{LANDASAN TEORI DAN HIPOTESIS}

\section{Pengertian Kompensasi}

Andrew E. Sikula mengemukakan bahwa:

The process of wage or salary administration (or, "compensation" as it is sometimes called) involves the weighing or balancing of accounts. A compensation is anything that constitutes or is regarded as an equivalent or recompense. In the employment world, financial rewards are the compensation resources provided to employees for the return of their services. The terms "remuneration", "wage", and "salary" also are used to describe this financial arrangement between employers and employees. A remuneration is a reward, payment, or reimbursements on occasion also may be nonfinancial in nature. Remunerations are usually in the form of comprehensive pay concepts than are the ideas of salary and wage that normally include a financial but not a nonfinancial dimension. ${ }^{6}$

Berdasarkan pendapat Andrew itu dapat dikemukakan bahwa proses administrasi upah atau gaji (kadang-kadang disebut kompensasi) melibatkan pertimbangan atau keseimbangan perhitungan. Kompensasi merupakan sesuatu yang dipertimbangkan sebagai suatu yang sebanding. Dalam kepegawaian, hadiah yang bersifat uang merupakan kompensasi yang diberikan kepada pegawai sebagai penghargaan dari pelayanan mereka. Bentuk-bentuk pemberian upah, bentuk upah, dan gaji digunakan untuk mengatur pemberian keuangan antara majikan dan pegawainya.

Menurut Rivai, kompensasi merupakan sesuatu yang diterima karyawan sebagai pengganti kontribusi jasa mereka pada perusahaan. Menurut Martoyo, "kompensasi adalah pengaturan keseluruhan pemberian balas jasa bagi employers maupun employees baik yang langsung berupa uang (finansial) maupun yang tidak langsung berupa uang (nonfinansial)

Menurut Edwin B. Flippo, "Wages is defined as the adequate and equitable renumeration of personnel for their constribution to

\footnotetext{
${ }^{6}$ Lewa, Eka Idham Iip K. \& Subowo. "Pengaruh Kepemimpinan, Lingkungan Kerja Fisik dan Kompensasi Terhadap Kinerja Karyawan di PT Pertamina (Persero) Daerah Operasi Hulu Jawa Bagian Barat, Cirebon”. 2005.
} 
organizational objectives". Upah didefinisikan sebagai balas jasa yang adil dan layak diberikan kepada para pekerja atas jasa-jasanya dalam mencapai tujuan organisasi).Menurut Bangun, kompensasi merupakan salah satu factor penting dan menjadi perhatian pada banyak organisasi dalam mempertahankan dan menarik sumber daya manusia yang berkualitas. Menurut Fajar dan Heru Kompensasi adalah seluruh extrinsic rewards yang didapat karyawan dalam bentuk upah, insentif, dan beberapa tunjangan (benefits). Kinerja atau produktivitas sumber daya manusia juga dapat dipengaruhi oleh banyak factor diantaranya kompensasi, lingkungan kerja, kepuasan kerja, dan motivasi. Salah satu yang menjadi pertimbangan kinerja karyawan adalah kompensasi yang adil dan lingkungan kerja yang sesuai. Hal ini didukung oleh penelitian yang dilakukan oleh Sudarsono, Rahmawati, Dharmawan, Murty dan Pramono dan Triyani. ${ }^{7}$

\section{Pengertian Motivasi}

Motivasi merupakan kondisi atau energy yang menggerakan diri karyawan yang terarah atau tertuju untuk mencapai tujuan organisasi perusahaan. Sikap mental karyawan yang pro dan positif terhadap situasi kerja itulah yang memperkuat motivasi kerjanya untuk mencapai motivasi kerja maksimal.

Menurut Robbins motivasi adalah proses yang ikut menentukan intensitas, arah, dan ketekunan individu dalam usaha mencapai sasaran.

Motivasi menurut Munandar adalah "suatu proses dimana kebutuhan-kebutuhan mendorong seseorang untuk melakukan serangkaian kegiatan yang mengarah ke tercapainya tujuan tertentu. Bila kebutuhan telah terpenuhi maka akan dicapai suatu kepuasan. Sekelompok kebutuhan yang belum terpuaskan akan menimbulkan ketegangan, sehingga perlu dilakukan serangkaian kegiatan untuk mencari pencapaian tujuan khusus yang dapat memuaskan kelompok kebutuhan tadi, agar ketegangan menjadi berkurang".

Pengertian motivasi kerja menurut Sadili Samsudin mengemukakan pernyataannya bahwa:

\footnotetext{
${ }^{7}$ Lewa, Eka Idham Iip K. \& Subowo. "Pengaruh Kepemimpinan, Lingkungan Kerja Fisik dan Kompensasi Terhadap Kinerja Karyawan di PT Pertamina (Persero) Daerah Operasi Hulu Jawa Bagian Barat, Cirebon”. 2005.
} 
"Motivasi kerja adalah sesuatu yang menimbulkan dorongan atau semangat kerja yang dipengaruhi oleh beberapa faktor, antara lain atasan, sarana fisik, kebijaksanaan, peraturan, imbalan jasa uang dan non uang, jenis pekerjaan dan tantangan".

.Malayu S.P. Hasibuan menyatakan bahwa motivasi kerja adalah pemberian daya penggerak yang menciptakan kegairahan kerja seseorang agar mereka mau bekerja sama, bekerja efektif, dan terintegrasi dengan segala daya upayanya untuk mencapai kepuasan. ${ }^{8}$ Sedangkan menurut T. Hani Handoko mengemukakan bahwa "motivasi adalah keadaan pribadi seseorang yang mendorong keinginan individu untuk melakukan kegiatan tertentu guna mencapai tujuan"

\section{Kinerja Karyawan}

Perusahaan memberikan kompensasi dengan harapan adanya rasa timbal balik dari karyawan tersebut untuk bekerja dengan prestasi yang baik. Hasibuan menyatakan bahwa kompensasi yang diterapkan dengan baik akan memberikan motivasi kerja bagi karyawan. Kompensasi yang diberikan harus layak, adil, dapat diterimakan, memuaskan, memberi moti-vasi kerja, bersifat penghargaan dan sesuai dengan kebutuhan. Pemberian kompensasi akan memberikan manfaat kepada kedua belah pihak, baik kepada pihak perusahaan maupun kepada pihak karyawan. Motivasi kerja sangat besar pengaruhnya terhadap kinerja seseorang. Seorang karyawan akan bekerja secara maksimal, memanfaatkan kemampuan dan ketrampilannya dengan bersemangat, manakala ia memiliki motivasi kerja yang tinggi. Motivasi kerja tersebut akan tampak jelas dalam bentuk keterlibatan kerja. Mereka yang memiliki motivasi kerja tinggi akan lebih terlibat dibanding mereka yang memiliki motivasi kerja rendah.

Banyak pendapat para ahli yang menerangkan keterkaitan antara motivasi kerja dan kinerja, diantaranya disampaikan oleh McClelland, , dalam Riggio, dengan teori achievement motivation, dimana pencapaian kinerja seseorang sangat dipengaruhi oleh motivasinya untuk memenuhi kebutuhan- kebutuhan (needs).

Kebutuhan tersebut terbagi menjadi, need for achievement, need for power dan need for affiliation. Seseorang yang ingin mendapatkan

\footnotetext{
${ }^{8}$ Mangkunegara, Anwar Prabu. Manajemen Sumber Daya Manusia Perusahaan. (Bandung: PT Remaja Rosdakarya Offset. 2017) 99.
} 
prestasi kerja atau kinerja yang tinggi, maka perilakunya diarahkan dalam bentuk bekerja dengan semangat kerja yang tinggi, memanfaatkan kemampuan dan ketrampilannya semaksimal mungkin, hingga diperoleh hasil kinerja yang tinggi pula. Perilaku orang tersebut termotivasi untuk memenuhi kebutuhan berprestasinya (need for achievement). ${ }^{9}$

Disamping itu terdapat beberapa aspek yang berpengaruh terhadap motivasi kerja pegawai, yaitu rasa aman dalam bekerja, mendapatkan gaji yang adil dan kompetitif, lingkungan kerja yang menyenangkan, penghargaan atas prestasi kerja dan pelakuan yang adil dari manajemen. Dengan melibatkan keputusan personalia dan memberikan umpan balik kepada para pegawai tentang pelaksanaan kerja mereka.

Begitu pula pendapat dari Victor Vroom, dalam Robbins, yang menyampaikan teori pengharapannya (expectancy theory), yang menguraikan bahwa seorang karyawan dimotivasi untuk menjalankan tingkat upaya yang tinggi bila ia meyakini upaya tersebut akan menghantar kepada penilaian kinerja yang baik, kinerja yang baik akan mendorong ganjaran-ganjaran organisasional, seperti pemberian bonus, kenaikan gaji, promosi, dan ganjaran lain yang akan memuaskan tujuan pribadi karyawan itu. Hal ini akan berpengaruh terhadap tingkat pencapaian kinerjanya, mengurangi ketidakhadiran, dan suatu kemungkinan istirahat yang mengurangi jam kerjanya.

$\mathrm{H}_{1}$ : Kompensasi berpengaruh positif dan signifikan terhadap kinerja karyawan

$\mathrm{H}_{2}$ : Motivasi berpengaruh positif dan signifikan terhadap kinerja karyawan.

\section{METODOLOGI PENELITIAN}

\section{Populasi dan Sampel}

Populasi merupakan wilayah generalisasi yang terdiri atas subjek atau objek yang memiliki karakter \& kualitas tertentu yang ditetapkan oleh seorang peneliti untuk dipelajari yang kemudian ditarik sebuah kesimpulan. Populasi dari penelitian ini adalah Objek dalam penelitian ini adalah internal auditor yang bekerja di beberapa Baitulmal wattamwil (BMT) se-kota tangerang. Dari sejumlah lembaga keuangan tersebut, hanya ada 5 kantor BMT yang bersedia memberikan ijin untuk melaksanakan penelitian ini yaitu

\footnotetext{
${ }^{9}$ Mangkunegara, Anwar Prabu. Manajemen Sumber Daya Manusia Perusahaan. 51.
} 
BMT Al-Muhajirin Barata, BMT Ubasyadah, BMT Rukun Abadi, BMT AlFurqon, dan BMT At Taqwa Pinang.

Sampel adalah suatu himpunan bagian (subset) dari unit populasi. Sampel adalah bagian dari suatu subjek atau objek yang mewakili populasi. Pengambilan sampel harus sesuai dengan kualitas dan karakteristik suatu populasi. Pengambilan sampel yang tidak sesuai dengan kualitas dan karakteristik populasi akan menyebabkan suatu penelitian akan menjadi biasa, tidak dapat dipercaya dan kesimpulannya pun bisa keliru. Hal ini karena tidak dapat mewakili populasi. Teknik pengambilan dengan Randhom Sampeling dari penelitian kali ini adalahJumlah kuesioner yang dibagikan untuk setiap BMT berkisar antara 1- 7 kuesioner, disesuaikan dengan jumlah karyawan BMT tersebut. Dari jumlah total kuesioner yang disebar dan dikirim, yaitu 35 kuesioner, jumlah kuesioner yang diisi dan dikembalikan adalah sebanyak 35 kuesioner. ${ }^{10}$

\section{Teknik Analisis Data}

Teknik pengolahan data dengan menggunakan metode SEM berbasis Partial Least Square (PLS) memerlukan 2 tahap untuk menilai Fit Model dari sebuah model penelitian. Tahap-tahap tersebut adalah sebagai berikut:

\section{Menilai Outer Model atau Measurement Model}

Terdapat tiga kriteria di dalam penggunaan teknik analisa data dengan SmartPLS untuk menilai outer model yaitu Convergent Validity, Discriminant Validity dan Composite Reliability. Convergent validity dari model pengukuran dengan refleksif indikator dinilai berdasarkan korelasi antara item score/component score yang diestimasi dengan Soflware PLS. Ukuran refleksif individual dikatakan tinggi jika berkorelasi lebih dari 0,70 dengan konstruk yang diukur. Namun menurut Chin, 1998 (dalam Ghozali, 2006) untuk penelitian tahap awal dari pengembangan skala pengukuran nilai loading 0,5 sampai 0,6 dianggap cukup memadai. Dalam penelitian ini akan digunakan batas loading factor sebesar $0,70 .{ }^{11}$

\footnotetext{
${ }^{10}$ Saydam, Ghozali. Manajemen Sumber Daya Manusia. (Jakarta: 1996. Djambatan) 71.

${ }^{11}$ M Nazir. Metode Penelitian. (Jakarta: Ghalia Indonesia. 2003) 174.
} 
TABEL 4.2

Outer Loadings (Measurement Model)

Outer Loading

\begin{tabular}{|l|l|l|l|}
\hline Matriks & & & \\
\hline & & & \\
\hline & kinerja & kompensasi & \\
\hline Kinerja1 & 0.955 & & \\
\hline Kinerja2 & 0.781 & & \\
\hline Kinerja3 & 0.958 & & \\
\hline Kinerja5 & 0.966 & & \\
\hline Kinerja6 & 0.824 & & \\
\hline Kompensasi5 & & 0.800 & \\
\hline Kompensasi6 & & 0.946 & \\
\hline Kompensasi7 & & 0.925 & \\
\hline Kompensasi8 & & 0.906 & \\
\hline Motivasi3 & & & \\
\hline Motivasi4 & & & \\
\hline Kompensasi5 & & & \\
\hline Kompensasi6 & & & \\
\hline Kompensasi7 & & & \\
\hline Kompensasi8 & & & \\
\hline Motivasi3 & & & \\
\hline Motivasi4 & & & \\
\hline Motivasi5 & & & \\
\hline Motivasi6 & & & \\
\hline Motivasi7 & & & \\
\hline Motivasi8 & & & \\
\hline Motivasi9 & & & \\
\hline & & & \\
\hline
\end{tabular}

Hasil pengolahan dengan menggunakan SmartPLS dapat dilihat pada Tabel 4.2. Nilai outer model atau korelasi antara konstruk dengan variabel pada awalnya belum memenuhi convergen validity karena masih cukup banyak indikator yang memiliki nilai loading factor di bawah 0,70. Modifikasi model dilakukan dengan mengeluarkan indikator-indikator yang memiliki nilai loading factor di bawah 0,70 . Pada model modifikasi sebagaimana pada tabel 4.2 tersebut menunjukkan bahwa semua loading factor memiliki nilai di atas 0,70 , sehingga konstruk untuk semua variabel sudah tidak ada yang dieliminasi dari model. 


\section{Statistik Deskriptif}

Beberapa indikator dari variabel penelitian tidak dapat digunakan dalam pengujian hipotesis, sehingga dalam penyajian analisis statistik deskriptif juga tidak akan disertakan. Statistik deskriptif dimaksudkan untuk menganalisis data berdasarkan atas hasil yang diperoleh dari jawaban responden terhadap masing-masing indikator pengukur variabel. Analisis statistik deskriptif dapat dilihat pada tabel 4.3.

\section{Tabel 4.3}

Statistik Deskriptif

\begin{tabular}{|l|l|l|l|l|l|l|}
\hline Variabel & $\mathrm{N}$ & Minimum & $\begin{array}{c}\text { Maximu } \\
\mathrm{m}\end{array}$ & Mean & Median & $\begin{array}{c}\text { Standar } \\
\text { Deviasi }\end{array}$ \\
\hline Kompensasi & 35 & 1,5 & 4,75 & 3,24 & 3 & 0,70 \\
\hline Motivasi & 35 & 2,28 & 5 & 3,46 & 3 & 0,72 \\
\hline $\begin{array}{l}\text { Kinerja } \\
\text { Karyawan }\end{array}$ & 35 & 2 & 4,2 & 3,12 & 3 & 0,60 \\
\hline
\end{tabular}

Sumber : Data primer yang teriolah

Berdasarkan data tersebut dapat ditunjukkan bahwa variabel kompensasi mempunyai kisaran teoritis antara 1,5 sampai dengan 4,75 dengan nilai rata-rata sebesar 3,24 dan standar deviasi sebesar 0,70. Dengan nilai rata-rata sebesar 3,24 yang lebih tinggi diatas nilai median(3), dapat dikatakan bahwa kompensasi memiliki nilai yang tinggi terhadap kinerja karyawan. Nilai standar deviasi menunjukkan adanya penyimpangan sebesar 0,70 dari nilai rata-rata jawaban respoden atas pernyataan tentang kompensasi yang besarnya 3,24.

Variabel motivasi mempunyai kisaran teoritis antara 2,28 sampai dengan 5 dengan nilai rata-rata sebesar 3,46 dan standar deviasi sebesar 0,72 . Dengan nilai rata-rata sebesar 3,46 yang lebih tinggi diatas nilai median(3), dapat dikatakan bahwa motivasi memiliki nilai yang tinggi terhadap kinerja karyawan. Nilai standar deviasi menunjukkan adanya penyimpangan sebesar 0,72 dari nilai rata-rata jawaban respoden atas pernyataan tentang motivasi yang besarnya 3,46 . 
Variabel kinerja karyawan mempunyai kisaran teoritis antara 2 sampai dengan 4,2 dengan nilai rata-rata sebesar 3,12 dan standar deviasi sebesar 0,60. Dengan nilai rata-rata sebesar 3,12 yang lebih tinggi diatas nilai median(3). Nilai standar deviasi menunjukkan adanya penyimpangan sebesar 0,60 dari nilai rata-rata jawaban respoden atas pernyataan tentang motivasi yang besarnya 3,12

TABEL 4.4

Nilai Discriminant Validity (Cross Loadings)

Validitas Diskriminan

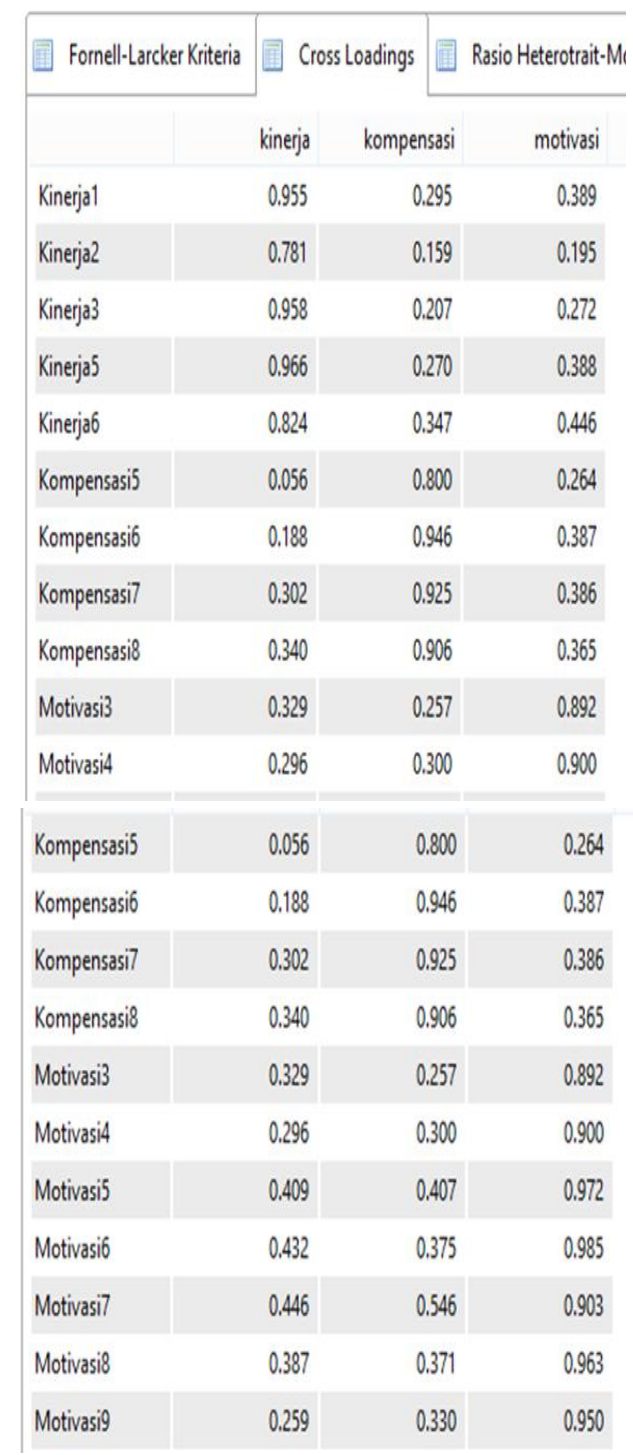

Sumber: Pengolahan data dengan PLS 
Dari tabel 4.4 dapat dilihat bahwa beberapa nilai loading factor untuk setiap indikator dari masing-masing variabel laten masih memiliki nilai loading factor yang tidak paling besar dibanding nilai loading jika dihubungkan dengan variabel laten lainnya. Hal ini berarti bahwa setiap variabel laten belum memiliki discriminant validity yang baik dimana beberapa variabel laten masih memiliki pengukur yang berkorelasi tinggi dengan konstruk lainnya.

3. Mengevaluasi Reliability dan Average Variance Extracted (AVE)

Kriteria validity dan reliabilitas juga dapat dilihat dari nilai reliabilitas suatu konstruk dan nilai Average Variance Extracted (AVE) dari masing-masing konstruk. Konstruk dikatakan memiliki reliabilitas yang tinggi jika nilainya 0,70 dan AVE berada diatas 0,50. Pada tabel 4.6 akan disajikan nilai Composite Reliability dan AVE untuk seluruh variabel.

TABEL 4.5

Composite Reliability dan Average Variance Extracted

\begin{tabular}{|c|c|c|}
\hline Variabel & $\begin{array}{c}\text { Composite } \\
\text { Reliability }\end{array}$ & $\begin{array}{c}\text { Average Variance } \\
\text { Extracted (AVE) }\end{array}$ \\
\hline Kompensasi & $\mathbf{0 , 9 4 2}$ & $\mathbf{0 , 8 0 3}$ \\
\hline Motivasi & $\mathbf{0 , 9 8 1}$ & $\mathbf{0 , 8 8 1}$ \\
\hline $\begin{array}{c}\text { Kinerja } \\
\text { Karyawan }\end{array}$ & $\mathbf{0 , 9 5 5}$ & $\mathbf{0 , 8 1 1}$ \\
\hline
\end{tabular}

Berdasarkan tabel 4.5 dapat disimpulkan bahwa semua konstruk memenuhi kriteria reliability. Hal ini ditunjukkan dengan nilai Composite Reliability diatas 0,70 dan AVE diatas 0,50 sebagaimana kriteria yang direkomendasikan.

4. Pengujian Model Struktural (Inner Model)

Pengujian inner model atau model structural dilakukan untuk melihat hubungan antara konstruk, nilai signifikansi dan R-square dari model penelitian. Model struktural dievaluasi dengan menggunakan Rsquare untuk konstruk dependen uji t serta signifikansi dari koefisien parameter jalur struktural. 
Gambar 4.1

Model Struktural

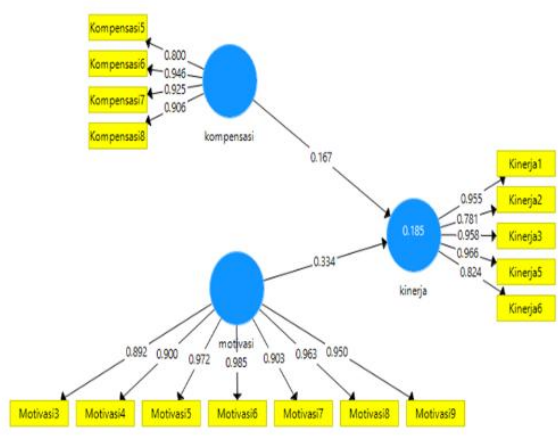

Dalam menilai model dengan PLS dimulai dengan melihat $R$ Square untuk setiap variabel laten dependen. Tabel 4.6 merupakan hasil estimasi $R$-Square dengan menggunakan SmartPLS.

TABEL 4.6

Nilai R-Square

\begin{tabular}{|c|c|}
\hline Variabel & R-Square \\
\hline Kinerja & 0.185 \\
Karyawan & \\
\hline
\end{tabular}

Sumber: Pengolahan data dengan PLS

Pada prinsipnya penelitian ini menggunakan 1 buah variabel yang dipengaruhi oleh variabel lainnya yaitu variabel Kinerja Karyawan yang dipengaruhi oleh Kompensasi dan Motivasi.

Tabel 4.6 menunjukkan nilai R-Square untuk variabel Kinerja Karyawan diperoleh sebesar 0.185. Hasil ini menunjukkan bahwa hubungan Kompensasi ke Kinerja Karyawan memberikan nilai estimasi parameter 0.167 dan signifikan pada 0.03. Dan Motivasi ke Kinerja Karyawan memberikan nilai estimasi parameter 0.334 dan signifikan pada 0.03. Jadi, Kompensasi dan motivasi mempengaruhi kinerja karyawan. Nilai R-Square sebesar 0.185 yang berarti variabilitas kompensasi dan motivasi yang dapat dijelaskan oleh kinerja karyawan hanya sebesar $18.5 \%$.

5. Pengujian Hipotesis

Signifikansi parameter yang diestimasi memberikan informasi yang sangat berguna mengenai hubungan antara variabel-variabel 
penelitian. Dasar yang digunakan dalam menguji hipotesis adalah nilai yang terdapat pada output result for inner weight. Tabel 4.7 memberikan output estimasi untuk pengujian model struktural.

TABEL 4.7

Result For Inner Weights

\begin{tabular}{|c|c|c|c|c|c|}
\hline & $\begin{array}{c}\text { Original } \\
\text { Sample }\end{array}$ & $\begin{array}{c}\text { Sample } \\
\text { Mean }\end{array}$ & $\begin{array}{c}\text { Standar } \\
\text { Deviasi }\end{array}$ & $\begin{array}{c}\mathrm{T} \\
\text { Statistics }\end{array}$ & $\begin{array}{c}\mathrm{P} \\
\text { Values }\end{array}$ \\
\hline $\begin{array}{c}\text { Kompensasi } \\
\rightarrow \text { Kinerja }\end{array}$ & 0.167 & 0.153 & 0.319 & 0.524 & 0.604 \\
\hline $\begin{array}{c}\text { Motivasi } \\
\rightarrow \text { Kinerja }\end{array}$ & 0.334 & 0.333 & 0.166 & 2.016 & 0.052 \\
\hline
\end{tabular}

Dalam PLS pengujian secara statistic setiap hubungan yang dihipotesiskan dilakukan dengan menggunakan simulasi. Dalam hal ini dilakukan metode bootstrap terhadap sampel. Pengujian dengan bootstrap juga dimaksudkan untuk meminimalkan masalah ketidaknormalan data penelitian. Hasil pengujian dengan bootstrapping dari analisis PLS adalah sebagai berikut:

a. Pengujian Hipotesis 1

Hasil pengujian hipotesis pertama menunjukkan bahwa hubungan antara Kompensasi dengan kinerja adalah tidak signifikan dengan T-Statistics sebesar $0.524<1.960$. Nilai original sample adalah positif yaitu sebesar 0.167 yang menunjukkan arah bahwa hubungan kompensasi dengan kinerja karyawan adalah positif. Dengan demikian hipotesis H1 dalam penelitian ini yang menyatakan bahwa 'Kompensasi tidak berpangaruh terhadap kinerja karyawan' diterima.

b. Penghasilan Hipotesis 2

Hasil pengujian hipotesis pertama menunjukkan bahwa hubungan antara Motivasi dengan kinerja adalah signifikan dengan TStatistics sebesar $2.016>1.960$. Nilai original sample adalah positif yaitu sebesar 0.334 yang menunjukkan arah bahwa hubungan motivasi dengan kinerja karyawan adalah positif. Dengan demikian hipotesis $\mathrm{H} 2$ dalam penelitian ini yang menyatakan bahwa 'Motivasi berpangaruh terhadap kinerja karyawan' diterima.

1) Pengaruh kompensasi terhadap kinerja karyawan 
Berdasarkan hasil perhitungan statistik, dapat disimpulkan bahwa konstruk kompensasi berpengaruh positif tidak signifikan terhadap konstruk kinerja karyawan secara langsung. Hal ini dapat dillihat dari nilai T-Statistics yang lebih kecil dari 1.960 yakni sebesar 0.524. Dengan demikian hipoesis H1 dalam penelitian ini diterima. Hal ini menunjukkan bahwa kompensasi cenderung tidak mempengaruhi kinerja seseorang.

2) Pengaruh motivasi terhadap kinerja karyawan

Berdasarkan hasil perhitungan statistik, dapat disimpulkan bahwa konstruk motivasi berpengaruh positif signifikan terhadap konstruk kinerja karyawan secara langsung. Hal ini dapat dillihat dari nilai T-Statistics yang lebih beasr dari 1.960 yakni sebesar 2.016. Dengan demikian hipoesis $\mathrm{H} 2$ dalam penelitian ini diterima. Hal ini menunjukkan bahwa motivasi cenderung mempengaruhi kinerja seseorang.

\section{KESIMPULAN}

Penelitian ini bertujuan untuk menganalisis pengaruh kompensasi dan motivasi terhadap kinerja karyawan BMT Se-kota Tangerang. Untuk meganalisis hubungan antar variabel tersebut, penelitian ini menggunakan Partial Least Square (PLS). Berdasarkan analisis dan pembahasan pada bagian sebelumnya, maka kesimpulannya adalah sebagai berikut:

1. Hasil uji hipotesis pertama menunujukkan bahwa hubungan kompensasi dengan kinerja karyawan berpengaruh positif dan tidak signifikan. Hal ini berarti bahwa besar kecilnya kompensasi yang diterima oleh karyawan BMT tidak mempengaruhi kinerja mereka dikantor.

2. Hasil uji hipotesis kedua menunjukkan bahwa adanya hubungan motivasi dengan kinerja karyawan berpengaruh positif dan signifikan. Hal ini menunjukkan bahwa motivasi sangat penting bagi para karyawan dalam meningkatkan kinerja nya.

\section{DAFTAR PUSTAKA}

Chrisnanda, Dody. 2017. Pengaruh Motivasi Kerja Terhadap Kinerja Karyawan di PT. MAS SUMBIRI. Skripsi. Universitas Sanata Dharma, Yogyakarta.

Fahmi, Irham. 2016.Pengantar Manajemen Sumber Daya Manusia. Lembaga Mitra Wacana Media, Jakarta. 
Fitriani. 2011. Pengaruh Motivasi Terhadap Kinerja Pegawai Administrasi Pada Bagian Umum Kantor Walikota Jakarta Utara. Skripsi. Institut Bisnis \& Multimedia, Jakarta.

Ghozali, Imam. 2008. Structural Equation Modeling Metode Alternatif dengan Partial Least Square. Badan Penerbit Universitas Diponegoro, Semarang.

Hasibuan, Malayu S.P. 2017. Manajemen Sumber Daya Manusia. PT Bumi Aksara, Jakarta.

Kasiram, Moh. 2008. Metode Penelitian Kualitatif-Kuantitatif. UIN-Malang Press, Malang.

Lewa, Eka Idham Iip K. \& Subowo. 2005. "Pengaruh Kepemimpinan, Lingkungan Kerja Fisik dan Kompensasi Terhadap Kinerja Karyawan di PT Pertamina (Persero) Daerah Operasi Hulu Jawa Bagian Barat, Cirebon",

Mangkunegara, Anwar Prabu. 2017. Manajemen Sumber Daya Manusia Perusahaan. PT Remaja Rosdakarya Offset, Bandung.

Nazir, M. 2003. Metode Penelitian. Ghalia Indonesia, Jakarta.

Saydam, Ghozali. 1996. Manajemen Sumber Daya Manusia. Djambatan, Jakarta. 
$168\}\{$ Pengaruh Kompensasi dan Motivasi Terhadap Kinerja Karyawan 